\title{
Kimberlitic minerals in Mafic--Ultramafic dikes in Spitsbergen
}

\author{
Alexander N. Evdokimov ${ }^{1}$, Alexander N. Sirotkin ${ }^{2}$, Marina Yu. Burnaeva ${ }^{1}$, \\ Elena S. Radina ${ }^{1}$
${ }^{1}$ VNIIOkeangeologiya (All-Russia Research Institute of Geology and Mineral Resources of the World Ocean), Saint-Petersburg, Russia
${ }^{2}$ Polar Marine Geological Exploration Expedition, Lomonosov, Russia

Since the discovery of diamond in kimberlites, the interest of geologists in these specific rocks has not faded away. The term "kimberlite" was proposed at the end of XIX century by H. Luis for diamondiferous rocks (volcanic peridotite with the porphyritic basaltic texture) from the Kimberley district in South Africa. The majority of researchers believe that kimberlite is a hypabyssal porphyritic rock. According to V.A.

Milashev (1991), one of the leading specialists in diamond geology, ultramafic and alkaline-ultramafic igneous rocks of the kimberlite facies must include barophile minerals, i.e., diamond and (or) pyrope garnet. Therefore, finds of pyrope and other kimberlitic accessory minerals in ultramafic and lamproite-type mafic magmatites are very important for the discovery of new kimberlite fields.

\section{Study areas}

The Mafic--Ultramafic dikes are located on West Spitsbergen Island (Norway) in the Devonian graben filled with redrocks (Evdokimov et. al., 2003) and are represented by five extended dikes of altered picrites in the northern area of the graben (eastern part of Andre Land) and by one serpentinized dike (Fig. 1) in the southern area of the graben (coast of the Ekman fjord, James I Land). Based on the low silica content and presence of mica, such rocks were previously referred to the lamprophyre association of the archipelago (Kovaleva, 1983).

The nearly vertical dikes (average thickness $0.5 \mathrm{~m}$ ) crosscut Devonian terrigenous rocks of the Gray Hook Formation and extend in the NNE direction. They are composed of rocks with porphyritic texture and massive structure. In picrites, the porphyritic phenocrysts are mainly composed of olivine, clinopyroxene, and biotite. Olivine phenocrysts are almost completely replaced by talc, serpentine, and carbonate. The groundmass is composed of chloritized and carbonatized glass with microlites of primarily pyroxene and biotite. Phenocrysts in the carbonatized basalt dike are partly albitized calcic plagioclase. Phenocrysts of pyroxene and completely carbonatized olivine are also found. The groundmass is composed of up to 0.5 -mm-long plagioclase laths, between which are xenomorphic segregations of pyroxene (near the dike center) or glass (near the contact).

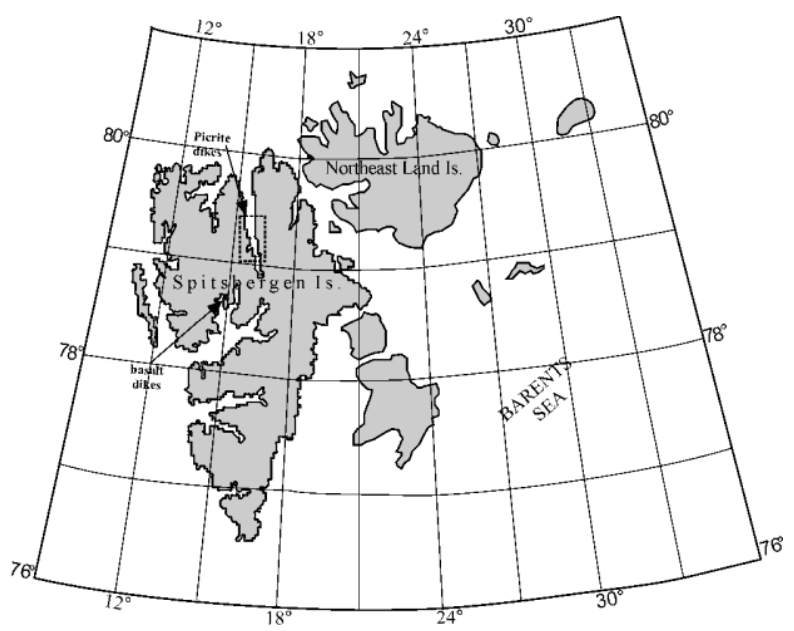

Fig.1 Location of dikes in Spitsbergen Is.

\section{Data base and analysis}

The composition of dikes are characterized by low contents of $\mathrm{SiO}_{2}$ and $\mathrm{MgO}(34.71 ; 15.71 \%)$. However, $\mathrm{Al}_{2} \mathrm{O}_{3}, \mathrm{CaO}$, and $\mathrm{TiO}_{2}$ are high $(7.56 ; 14.44 ; 1.36 \%)$. They can be referred to the group of alkaline rocks based on the sum of alkali metals $\left(\mathrm{Na}_{2} \mathrm{O}+\mathrm{K}_{2} \mathrm{O}=1,75-\right.$ $3,13 \%)$. With respect to alkalinity, picrites in Andre Land belong to the $\mathrm{K}-\mathrm{-Na}$ and $\mathrm{K}$ types, whereas carbonatized basalt of James I Land belong to the $\mathrm{Na}$ type. Identification of these rocks is based on texture, mineralogy, and chemistry, with the consideration of secondary alterations (Le Bas, 2000).

The deep origin of picrites is indicated by the small amount of xenoliths of dunites, spinel lherzolites, and wehrlites up to $3 \mathrm{~cm}$ in size.

The geological age of the carbonatized basalt of James I Land was determined at the exposure. Lower Devonian redrocks are crosscut by the dike, which is overlain by Middle Devonian carbonate rocks. Results of $\mathrm{Rb}-\mathrm{-Sr}$ and $\mathrm{K}-\mathrm{-Ar}$ datings indicate that the picrites have an Early--Middle Carboniferous age (Table 1). 
Table 1

Absolute age of dikes in Spitsbergen Is. (Ma)

\begin{tabular}{|c|c|c|}
\hline Sample & Rb-Sr method & K-Ar method \\
\hline 41-23 (Dike 2) & $334,8 \pm 3,8$ & $357 \pm 28,6$ \\
$41-24$ (Dike 3) & $315,0 \pm 3,0$ & $297 \pm 23,8$ \\
222-7 (Dike 5) & $326,8 \pm 2,6$ & $422 \pm 33,8^{*}$ \\
\hline
\end{tabular}

* Error in this determination can be significantly higher

Panning mineralogical sample $7(15.3 \mathrm{~kg})$ taken from a picrite dike in the Purpur Dallen Valley yielded $102.3 \mathrm{~g}$ of the heavy fraction that contained 24 pyrope grains together with chrome diopside and chrome spinels. Nuggets of kimberlitic accessory minerals (chrome spinels, chrome diopside, and moissanite) were found in two picrite dikes. In the feldspar-containing basalt sample (weight $9.9 \mathrm{~kg}$, heavy concentrate $0.77 \mathrm{~g}$ ), we found six nuggets of pyrope, nine grains of chrome diopside, and a few grains of chrome spinels.

Identification of pyropes was based on their color, refractive index, and chemical composition. They occur as clasts $(0.2--0.8 \mathrm{~mm})$ of pink and red colors with lilac tints in the picrites and of violet-red color in the carbonatized basalt. Specific features of the $\mathrm{Cr}_{2} \mathrm{O}_{3--}$ $\mathrm{CaO}$ relationship in the pyropes are shown on fig. 2 . One data point from the basalt dike falls into the pyrope domain of the diamondiferous assemblage, while other data points are typical of pyropes of the lherzolite assemblage in kimberlites.

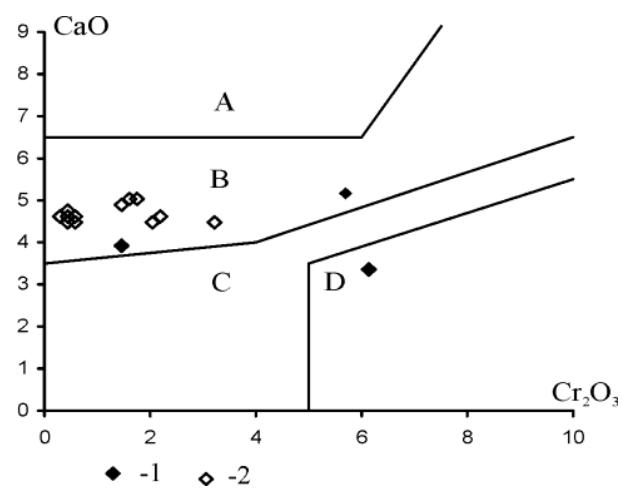

Fig. $2 \mathrm{Cr}_{2} \mathrm{O}_{3}-\mathrm{CaO}$ relationship in $\mathrm{Cr}$-bearing garnets and pyropes from dikes on the Spitsbergen Is. Compositional fields of garnets (Sobolev, 1974) from: (A) wehrlites, (B) lherzolites, (C) dunite--harzburgites, and (D) pyropes included in diamond. $(1,2)$ Pyropes from dikes on Spitsbergen: (1) carbonatized basalt dike, (2) picrite dike.

The emerald-green chrome diopside is found as rare xenomorphic grains $(0.1--0.5 \mathrm{~mm})$ with the maximal $\mathrm{Cr}_{2} \mathrm{O}_{3}$ content of $1.6 \mathrm{wt} \%$. In terms of the contents of $\mathrm{MgO}, \mathrm{CaO}, \mathrm{Al}_{2} \mathrm{O}_{3}$, and $\mathrm{Cr}_{2} \mathrm{O}_{3}$, chrome diopside grains from picrites of Spitsbergen are similar to pyroxenes from lamproites (Dobretsov et. al., 2001), while chrome diopside grains from the basalt dike are similar to those from the diamondiferous nodules in kimberlites (Fig. 3).
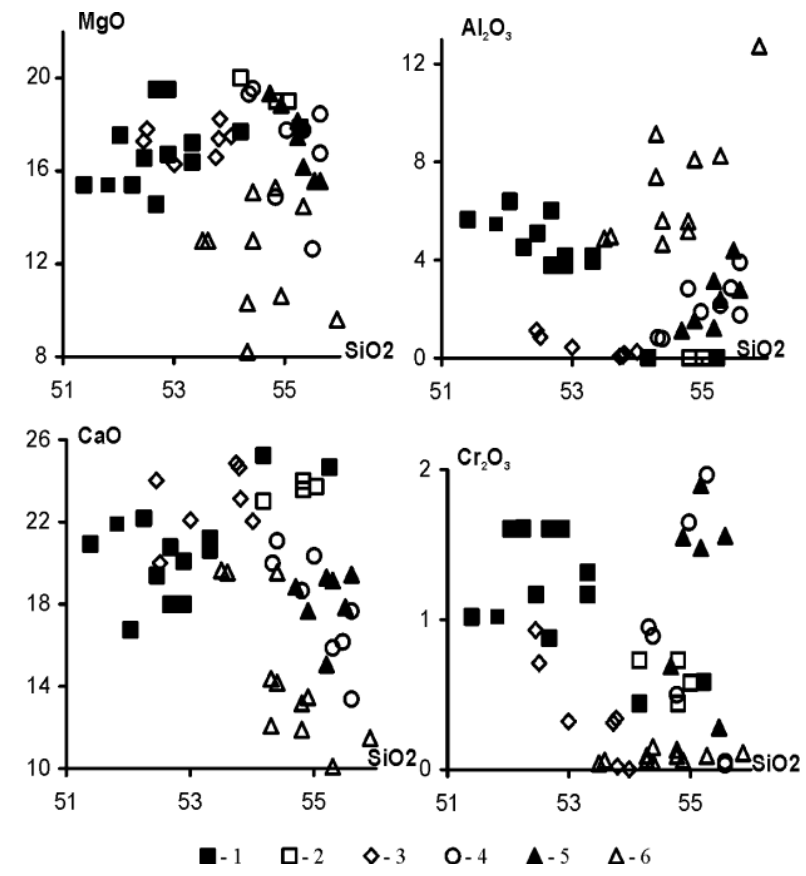

Fig. 3 Pyroxene compositions in dikes (Spitsbergen), kimberlites and lamproites (adopted from Dobretsov et. al., 1971). (1, 2) Dikes in Spitsbergen: (1) picrites in Andre Land, (2) carbonatized basalt dike in James I Land; (3) lamproites (Australia); (4--6) kimberlites (Yakutia): (4) diamondiferous nodules, $(5,6)$ hosted in diamond of the ultramafic and eclogitic assemblages, respectively.

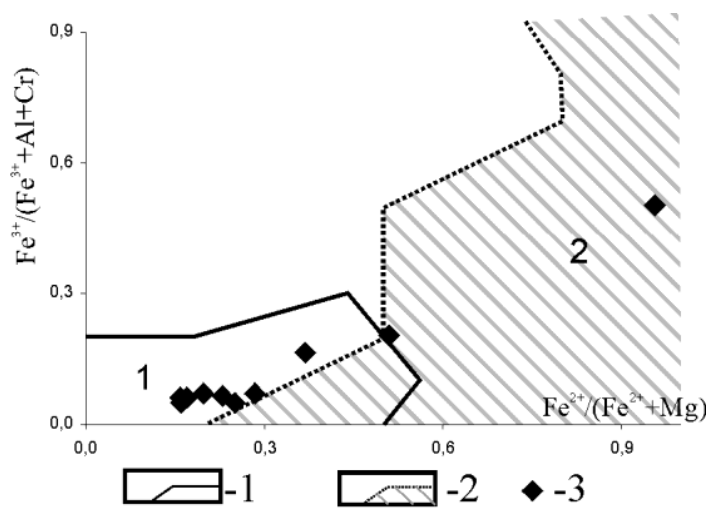

Fig. $4 \mathrm{Fe}^{2+} /\left(\mathrm{Fe}^{2+}+\mathrm{Mg}\right)-\mathrm{Fe}^{3+} /\left(\mathrm{Fe}^{3+}+\mathrm{Al}+\mathrm{Cr}\right)$ relationship in chrome spinels from dikes in Spitsbergen. (1, 2) Compositional fields of chrome spinels (Vaganov et. al., 1999) from (1) diamondiferous kimberlites and lamproites and (2) diamond-free nonkimberlitic rocks; (3) chrome spinels from Paleozoic dikes in Spitsbergen.

Chrome spinels occur as black or brownish black clastic and euhedral grains $(0.2--0.8 \mathrm{~mm})$, with the $\mathrm{Cr}_{2} \mathrm{O}_{3}$ content varying from 10.2 to $54.0 \mathrm{wt} \%$ (Table 1). In the summary diagnostic diagram (Fig. 4), data points of chrome spinels from Spitsbergen fall into the domain of chrome spinels from the diamondiferous kimberlites and lamproites. 
One of the important special features of the structural position of kimberlite is their arrangement in the limits of the blocks of ancient crystalline base with the formation of the compact groups, united into the fields extent about $100 \mathrm{~km}$. Kimberlitic fields in turn, are erected for example in Polar Yakutiya into the extensive zones with a length of up to $1000 \mathrm{~km}$. It is possible that dikes on Spitsbergen are the fragment of a similar zone of kimberlitic volcanism.

\section{Summary and conclusions}

Taking into account the findings of kimberlitic accessory minerals (pyrope, chrome diopside, and chrome spinel) in porphyritic ultramafic rocks of Spitsbergen, as well as the absolute age of Paleozoic dikes in the archipelago, which coincides with the Carboniferous kimberlitic magmatism on the Zimnii coast (Arkhangelsk district) and Kola Peninsula, the picrite dikes in Spitsbergen (primarily, the best-studied dike 7) can be assigned to the pyrope facies of kimberlitic magmatism. The association of kimberlites, porphyritic picrites, and alkaline basaltic rocks is known in kimberlite fields of the Yakutian kimberlite province and in Greenland. Therefore, the spatial association of kimberlites of Spitsbergen with the carbonatized basalt dikes is quite natural.

According to Harland (1978), Spitsbergen was detached from Greenland during the opening of the North Atlantic Ocean. Therefore, kimberlites of Spitsbergen can represent the Paleozoic member of the Greenland kimberlite province that existed in the Early Proterozoic - Mesozoic (Larsen \& Rex, 1992).

The second neighbor of the Spitsbergen kimberlite province is represented by diamondiferous diatremes on the Zimnii coast (Arkhangelsk district). They make up a single continent with Spitsbergen in the field of Proterozoic metamorphic basement.

The paleotectonic reconstructions of the region showed that the amplitude of horizontal motions was commensurate with the observed width of riftogenic depressions. For example, summary displacement of Central-Barentsevskiy and Svalbardskiy blocks relative to Pechora one are evaluated at 300 and $200 \mathrm{~km}$ respectively (Artyushkov, 2004; fig. 5). This estimation is executed according to the simplified diagram, at basis of which lies the assumption that if the crust under the riftogenic depression is thinner than on its arms to $10 \%$, then the portion of the horizontal extension of groove composes approximately $10 \%$ of its width, and the remaining space of groove is filled with the fragments of prerifting structure, went down along the system of boundary breakings, including on listrium type faults.

The Early--Middle Carboniferous absolute age of Spitsbergen dykes fall into the interval of 340--360 Ma, which fits the kimberlites of Archangelsk district (Sablukov, 1995). Thus, one cannot rule out the existence of a northwestern (Spitsbergen) branch of the Russian kimberlitic province.

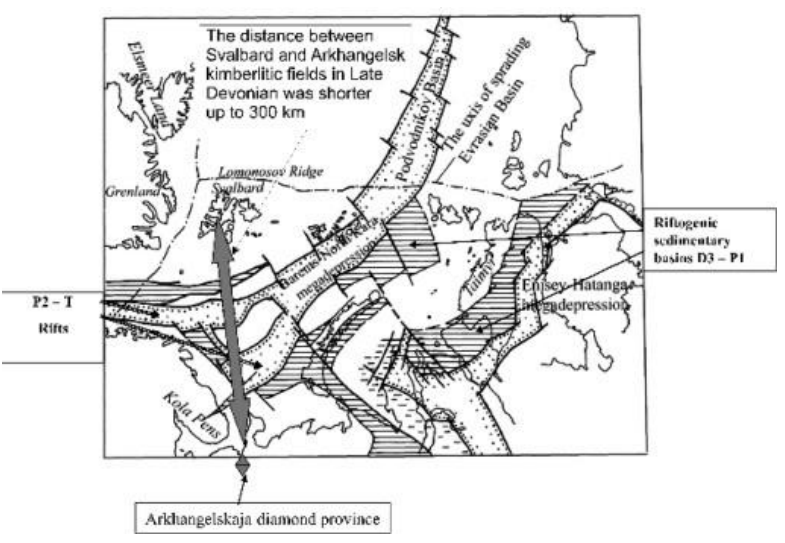

Fig. 5 Reconstruction of $\mathrm{D}-\mathrm{T}$ riftogenic structure in the Euro-Arctic region (Verba \& Verba, 2002) with author's additions.

\section{References}

Artyushkov E.V., 2004. Mechanism of the formation of Barents sedimentary basin. In: Evolution of tectonic processes in the history of the Earth. 2. $13-15$. Novosibirsk (in Russian).

Dobretsov N. L., Kochkin Yu. N., Krivenko A. P. \& Kutolin V. A., 1971. Rock-Forming Pyroxenes. Nauka, 454. Moscow (in Russian).

Evdokimov A. N., Sirotkin A. N., Teben'kov A. M., Burnaeva M.Yu. \& Radina Ye.S., 2003. Kimberlite dikes of Spitsbergen archipelago. In: Complex Investigations of the Nature of Spitsbergen. 80-85. Apatity (in Russian).

Harland W. B., 1978. The Caledonides of Svalbard: IGCP Project 27, Caledonian-Appalachian orogen of the North Atlantic region. Canada Geological Survey Paper 78-13, 3-11.

Kovaleva G. A., 1983. Post Archean basit-ultrabasite association. In: Geology of Spitsbergen, 87-95. Mingeo SSSR, Leningrad (in Russian).

Larsen L.M. \& Rex D.C., 1992. A review of 2500 Ma span of alkaline-ultramafic, potassic and carbonatitic magmatism in West Greenland. Amsterdam. Lithos $28,367-402$.

Le Bas M. J., 2000. IUGS reclassification of the high-Mg and picritic volcanic rocks. Journal of Petrology 41- 10. $1467-1470$.

Milashev V. A., 1991. History of knowledge, terminological aspects and contemporary of the taxonomist of kimberlitic rocks. Geology \& Geophysics 6, 26 34 (in Russian).

Sablukov S. M., 1995. Volcanism of Zimniy shore and the petrological criteria of diamondbearing of kimberlite. Author's Abstract of dissertation. TsNIGRI, $24 \mathrm{pp}$. Moscow (in Russian).

Sobolev N. V., 1974. Deep Inclusions in Kimberlites and problem of composition of the Upper Mantle. Nauka, Novosibirsk, 264 (in Russian).

Vaganov V. I., Ilupin I. P. \& Kocherov A. I., 1999. Chromspinellids as indicator of diamond content. Rudy \& Metally 3, 35- 47 (in Russian).

Verba V.V. \& Verba M.L., 2002. Structures of the tension of the Earth's crust in the Arctic region. In: Russian Arctic: geological history, minerageniya, geoecology. VNIIOkeangeologiya. 93-108. St. Petersburg (in Russian). 